\title{
Recurrent syncope while eating: an unusual presentation of a diaphragmatic hernia
}

\author{
Kevin B Harris (10 , Andrei Brateanu
}

Medicine Institute, Cleveland Clinic Foundation, Cleveland, Ohio, USA

\section{Correspondence to Dr Kevin B Harris; harrisk5@ccf.org}

Accepted 10 April 2020
A Check for updates

(c) BMJ Publishing Group Limited 2020. No commercial re-use. See rights and permissions. Published by BMJ.

To cite: Harris KB,

Brateanu A. BMJ Case

Rep 2020;13:e233641.

doi:10.1136/bcr-2019-

233641

\section{DESCRIPTION}

A male patient with dementia, benign prostatic hyperplasia and chronic hepatitis $C$ presented with a several month history of syncope while eating.

The ECG, echocardiogram, electroencephalogram, brain CT and carotid ultrasound were unrevealing. The chest and abdominal radiographs showed a possible eventration or herniation of the left hemidiaphragm (figure 1). The chest CT revealed a large leftsided Bochdalek hernia with the stomach and colon herniated into the thorax (figure 2). The patient was managed conservatively with adjustment of meal size and discharged to an assisted living facility. To the best of our knowledge, the patient had no recurrent episodes of syncope.

Bochdalek hernia is a congenital diaphragmatic hernia, typically discovered in infancy. In adults, it is rare and usually discovered incidentally. ${ }^{1}$ When symptomatic, the most common complaint is pain. ${ }^{2}$ On rare occasions, the diaphragmatic hernia can manifest as syncope or presyncope while dining. ${ }^{34}$ A recent review of the literature revealed 19 cases of hernia induced syncope. ${ }^{5}$ When the syncope is associated with eating it is also known as deglutition syncope. This type of syncope is thought to occur due to a vagal reflex during swallowing that causes inhibition of the normal cardiac conduction system. It is also associated with severe peripheral vasodilatation, bradycardia and hypotension. ${ }^{6}$ Large hernias may also cause left atrial and left ventricular compression and reduced right ventricular outflow tract diameter. ${ }^{7}$ In these cases, the syncope occurs as a result of the underfilling of the left atrium from stomach distension while eating. ${ }^{8}$ When surgical intervention and correction of the defect is not possible, a smaller meal size may improve the symptoms. ${ }^{5}$

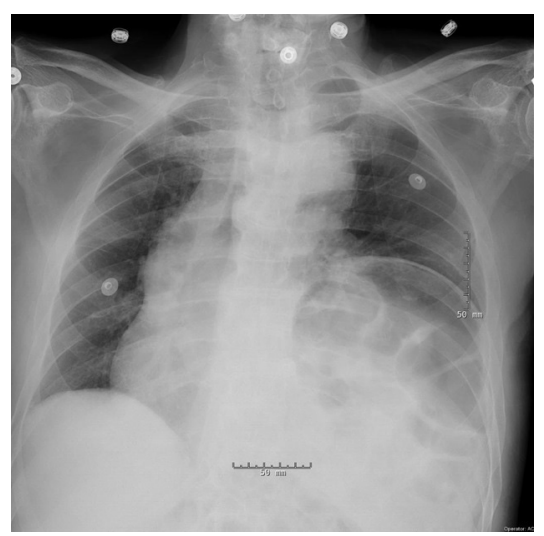

Figure 1 Chest X-ray showing herniation of the left hemidiaphragm.

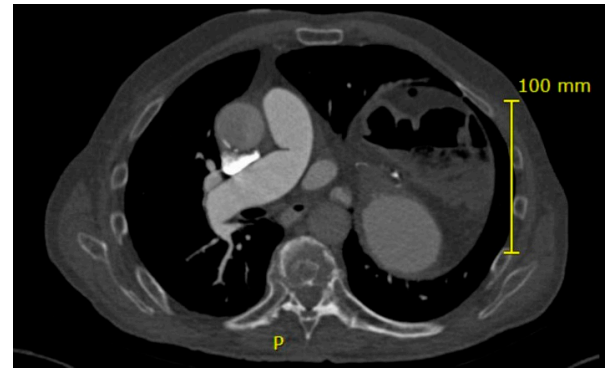

Figure 2 CT scan of the chest with a large left-sided Bochdalek hernia showing the stomach and colon herniated into the thorax.

\section{Learning points}

Bochdalek hernias (congenital diaphragmatic hernias) may present as syncope or presyncope while eating.

- When surgical correction of the hernia is not possible, decreasing meal size can improve symptoms of prandial syncope.

Contributors $\mathrm{KBH}$ is the primary author of manuscript. $A B$ edited the manuscript and is the article guarantor.

Funding The authors have not declared a specific grant for this research from any funding agency in the public, commercial or not-for-profit sectors.

Competing interests None declared.

Patient consent for publication Not required.

Provenance and peer review Not commissioned; externally peer reviewed.

\section{ORCID iD}

Kevin B Harris http://orcid.org/0000-0002-3515-7476

\section{REFERENCES}

1 Mullins ME, Stein J, Saini SS, et al. Prevalence of incidental Bochdalek's hernia in a large adult population. AJR Am J Roentgenol 2001;177:363-6.

2 Brown SR, Horton JD, Trivette E, et al. Bochdalek hernia in the adult: demographics, presentation, and surgical management. Hernia 2011;15:23-30.

3 Gunaruwan P, Napthali K, Nair K. "Unusual presentation of a common problem". BMJ Case Rep 2013

4 Yildiz A, Tuncez A, Demirkan B, et al. An unusual cause of syncope: diaphragmatic hernia. Echocardiography 2013;30:E136-7.

5 Siew KSW, Tan MP, Hilmi IN, et al. Swallow syncope: a case report and review of literature. BMC Cardiovasc Disord 2019;19:191.

6 Patel N, Ibrahim S, Shah J, et al. Deglutition syncope. Proc 2017;30:293-4.

7 Naoum C, Kritharides L, Falk GL, et al. Left atrial compression and right ventricular outflow tract diameter on echocardiography are independently associated with exercise capacity in patients with large hiatal hernia. Echocardiography 2018;35:592-602.

8 Walpot J, Amsel B, Pasteuning WH, et al. Left atrial compression caused by hiatus hernia: a rare cause of syncope. Acta Clin Belg 2011;66:422-5 
Images in...

Copyright 2020 BMJ Publishing Group. All rights reserved. For permission to reuse any of this content visit https://www.bmj.com/company/products-services/rights-and-licensing/permissions/

BMJ Case Report Fellows may re-use this article for personal use and teaching without any further permission.

Become a Fellow of BMJ Case Reports today and you can:

- Submit as many cases as you like

- Enjoy fast sympathetic peer review and rapid publication of accepted articles

Access all the published articles

Re-use any of the published material for personal use and teaching without further permission

Customer Service

If you have any further queries about your subscription, please contact our customer services team on +44 (0) 2071111105 or via email at support@bmj.com.

Visit casereports.bmj.com for more articles like this and to become a Fellow 